ća. Stoga se, prema mojemu sudu, može reći da smo i ovim zbornikom dobili materijal koji budućim istraživačima Petrovićeva filozofskog rada može poslužiti kao korisna građa za istraživanje neposredne recepcije Petrovićeva djela te kao sekundarna literatura u vezi posebnih problema iz Petrovićeva opusa.

Nakon što sam iznio osnovne podatke o ovome zborniku, smjestio ga u kontekst i ponudio osnovnu prosudbu o njegovu sadržaju, u posljednjem dijelu ovoga prikaza u nekoj ću mjeri apstrahirati od konkretnog sadržaja ovoga zbornika da bih barem u osnovnim crtama postavio problem postumne recepcije djela Gaje Petrovića (ali i drugih suradnika časopisa Praxis, kao i samog časopisa te Korčulanske ljetne škole). To ću početi dvama pitanjima koja mi se čine najpogodnijima, a glase: (1) Što bi bila adekvatna recepcija našeg filozofskog nasljeđa druge polovice prošloga stoljeća? (2) Omogućuju li takvu recepciju komemorativni skupovi i zbornici?

Odgovore na postavljena pitanja možda ni ne treba tražiti izvan našeg filozofskog nasljeđa. Stoga ću navesti tri izvora za koja smatram da mogu pomoći u konstrukciji tih odgovora. Prvi je izvor neupitna tendencija prema sistematizaciji znanja o filozofiji koja je prisutna u našoj filozofiji još od Povijesti filozofije I-III Alberta Bazale (1906., 1909., 1912.) Savremene filozofije Vladimira Dvornikovića (1919.) u razdoblju prije Drugog svjetskog rata. U razdoblju, pak, nakon rata, ta se tendencija očitovala u još više primjera od kojih ću navesti samo neke: Filozofska hrestomatija Matice hrvatske u 12 svezaka, koja je realizirana u četiri izdanja od 1956. do 1983. godine; Historija marksizma Predraga Vranickog, koja je realizirana u četiri izdanja od 1961 do 1987. godine i koja je bila prva historija marksizma u svijetu; Leksikon filozofa Danka Grlića, koji je u razdoblju od 1968. do 1983. realiziran u tri izdanja; Filozofijski rječnik koji je u razdoblju 1965. do 1989. realiziran također u tri izdanja. Drugi su izvor prosudbe o informiranosti o našem filozofskom nasljeđu razdoblja kojemu pripada Gajo Petrović a koje su ponudili Lino Veljak u svojoj knjizi Prilozi kritici lažnih alternativa (2010.) i Božidar Jakšić u knjizi Praxis. Mišljenje kao diverzija (2012.). Veljak je, naime, zapisao da je "stupanj informiranosti novih generacija o Praxisu i Školi očekivano (...) nizak« te izrazio zabrinutost da se »glavnina te informiranosti sastoji od legendi, tračeva i podataka koji su po svom karakteru ili poluistine ili čak i laži«. Ta Veljakova prosudba dodatno se potvrđuje i čitanjem Jakšićeve knjige, odakle možemo doznati i to da širenje onoga što je Veljak nazvao poluistinama i lažima nije novost, već ustaljena praksa koja je započela već prvih godina izlaženja Praxisa, a traje do danas. Naposljetku, treći izvor, koji smatram važnim, programatski je tekst koji je pod naslovom »Pola stoljeća Hrvatskog filozofskog društva kao istraživački izazov« objavio Goran Grgec. Naime, Grgec je u tom tekstu naznačio strukturu relevantnih podataka prikupljanjem kojih bismo mogli opisati Praxis i Korčulansku ljetnu školu u širem okviru povijesti Hrvatskog filozofskog društva.

Da zaključim, smatram da su urednik i izdavač ovoga zbornika ponudili izdanje koje je vrijedno na više razina. Prva od njih je, čini mi se, razina refleksivne svijesti stručne javnosti koja je ovime dobila podsjetnik na lik i djelo jednoga od najznačajnijih, ako ne i najznačajnijeg, našeg filozofa u posljednjih pola stoljeća. Druga je razina ona na kojoj se odvija istraživački povijesno-filozofski rad i na kojoj je, kao što sam već naveo, ovaj zbornik vrijedna građa za buduće istraživače koji će liku i djelu Gaje Petrovića posvetiti svoje sustavne i dugotrajne istraživačke napore. Naposljetku, imajući potonju razinu u vidu, smatram da će vrijednost ovoga, ali i sličnih izdanja biti u potpunosti prepoznata tek iz perspektive budućih istraživanja, na čije će rezultate ovo izdanje nesumnjivo utjecati. Ostaje se, stoga, nadati da će takva istraživanja biti institucionalno omogućena na vrijeme, tako da njihovi rezultati budu prezentirani do tridesete obljetnice smrti Gaje Petrovića i pedesete obljetnice zabrane Praxisa i Korčulanske ljetne škole, koje nas očekuju u prvoj polovici sljedećeg desetljeća.

\section{Luka Matić}

doi: $\underline{10.21464 / f i 36114}$

\section{Predrag Finci}

\section{Estetska terminologija}

\section{Izdanja Antibarbarus, Zagreb 2014.}

Estetska terminologija opsežno je djelo u kojemu se na gotovo pet stotina stranica iznose problemi i razmatranja vezani za estetiku filozofiju umjetnosti. Pored uobičajenih bibliografskih jedinica i predmetnog kazala, opsežnosti same knjige pridonosi i koristan zanimljiv kratki bio-bibliografski pregled filozofa relevantnih za pitanja umjetnosti. Sam bio-bibliografski prikaz nije suviše iscrpan, 
ali je sasvim dovoljan da potencijalnog čitatelja zainteresira za neki estetski problem i u tom se smislu pokazuje korisnim kao smjer i pomoć pri daljnjem istraživanju. S obzirom na metodički pristup izlaganju materije, knjiga se čini korisnom za studente i one koji probleme i teme filozofske estetike već poznaju te žele produbiti svoje znanje, ali i one koji se $\mathrm{s}$ navedenim područjem tek namjeravaju upoznati. Pisana jasnim i razumljivim jezikom (autor već u uvodu ističe zahtjev koji je pred sebe stavio: »Pritom bi trebalo stvari iskazati što je jasnije, što je razgovjetnije moguće, a ne tamno činiti još tamnijim«, str. 15), Fincijeva Estetska terminologija jasno i pregledno upoznaje čitatelja s mnogim pitanjima estetike i filozofije umjetnosti, informira o općim mjestima i daljnjim mogućim smjerovima istraživanja te otvara probleme koje ne pokušava konačno razriješiti već naznačiti neke od odgovora koje je moguće ponuditi.

U jedanaest fragmentarno strukturiranih poglavlja, pri čemu je i sam fragment kao izneseni problem razdijeljen na početnu tezu, raspravu i svojevrsni zaključak s obzirom na iznesenu tezu, Predrag Finci iznosi povijesni razvoj područja umjetničkog, umjetnosti i samih umjetničkih predmeta, bitna pitanja i neke od mogućih odgovora na njih te teorijski osvrt na konstituciju pojedinog umjetničkog područja, prakse i mogućih značenja koja umjetnost može zauzimati ili zauzima. Sve to izneseno je na temelju vlastitog estetskog iskustva, promišljanja i doživljavanja umjetnosti. Iako nazvana Estetska terminologija, Fincijeva knjiga nije zbroj abecedno poredanih ključnih estetskih termina i pojmova, već znanstvena i filozofijska rasprava o ključnim problemima estetike kao filozofske discipline, povijesnoj dimenziji umjetnosti i teorijskom utemeljenju umjetničkoga područja. S obzirom na metodološki odmak i interdisciplinarni pristup estetici i umjetnosti, Fincijeva knjiga nije tek jedan u nizu priručnika ili pregleda pojmova važnih za filozofiju, ona je stvaran doprinos promišljanju umjetnosti i osnaživanju znanstvenoga aparata kojim je uopće moguće govoriti ili misliti o umjetnosti.

Upravo je misliti umjetnost jedan od izazova na koji upozorava $\mathrm{i}$ autor $\mathrm{u}$ istoimenom $\mathrm{pr}$ vom poglavlju. To da se misli nešto pretpostavlja definiranje onoga o čemu se uopće misli. Takav zadatak izaziva na konstituiranje temeljnih pojmova kojima se uopće obuhvaća predmet koji se misli, onakav kakav jest u pojmu od kojega polazimo u bilo kojoj filozofskoj disciplini pa tako i u slučaju estetike. Zadatak da se o umjetnosti misli, pa da se misli i znanstveno kako o umjetnosti progovara estetika, može biti otežan bilo odbijanjem subjekta da misli i prepusti se afektu koji stvara umjetnički fenomen ili ograničenjem samog mišljenja i njegovih granica da se na pitanja o biti umjetnosti odgovori u konačnosti. Kao fenomen i dio svijeta koji nas okružuje, umjetnost zahtijeva da se o njoj ipak misli i govori znanstveno, a ograničenja samoga mišljenja i složenost fenomena umjetnosti upućuju nas na metodologiju kojom se ovdje pristupilo umjetnosti - rezultati nisu i ne mogu biti konačni, a fragmentiranost iznošenja problema i struktura poglavlja znak su nužnost interdisciplinarnog pristupa $u$ istraživanju biti umjetnosti kao fenomena koji nužno mora biti sagledan iz svih relacija koje spram čovjeka i svijeta ostvaruje. Osim kakvo je za sebe, umjetničko djelo tako valja postaviti u kontekst odnosa koje ostvaruje npr. s društvom, politikom, religijom, tržištem, publikom, institucijama, različitim teorijama umjetnosti pa i povijesno uvjetovanog shvaćanja same umjetnosti i, ponekad, njenih funkcija koje ima ili može imati. U tom je smislu povijest umjetnosti svijest o njenom povijesnom karakteru, ono što je ona bila, ali i ono što je za nas danas. Takva promjenjivost umjetnosti možda može biti potvrđena i suvremenim tehničkim promjenama u smislu dominacije lako propadljivih materijala ili umjetnosti trenutka kao što su instalacija ili performans nad umjetničkim djelima namijenjenima vječnosti, ali ukoliko o promjeni kao specifično umjetničkom obilježju uopće možemo govoriti, utoliko se otkriva specifičan odnos umjetničkih djela spram vlastitog vremena, ali i mogućnost umjetnosti da transcendira povijesna razdoblja. U tom se smislu uopće možemo pitati o klasičnoj ili suvremenoj umjetnosti i njenom značaju za nas. Dijelimo li umjetnost prema trenutku nastajanja, mediju, materijalu, funkciji, svojstvima ili rodovima, jedina izvjesnost umjetnosti je izvjesnost osjetilnosti u kojoj se umjetnost ostvaruje, pri čemu sve više interferiraju različita osjetila ili $\mathrm{su}$, tradicionalno pojmljeno, ona odvojena u pojedinom umjetničkom mediju. Umjetnost je, tvrdi se, ostvarena osjetilnost, osjetilno izražena priroda bića i sklad s bitkom kojega iskazuje. Pored do sada društvenih uvjeta, poredaka ili zakonitosti same umjetnosti, Finci jedinu uvjetovanost umjetnosti pronalazi u samom bitku.

Središnji dio knjige čini srž onoga što možemo shvatiti problemski koncipiranom terminologijom čitanom u ključu početnog i završnog poglavlja. Od izvora ili ishodišta umjetničkog djela u poglavlju »Djelo po ishodištu« i s postupnim prevladavanjem historijski i pojmovno razmotrenih koncepata umjetnosti, kao što su oponašanje ili stvaralaštvo (te za njega nužnih autonomije i slobode koje u konačnici vode do igre kao slobodnog i stvaralačkog 
ljudskog modusa), razrada problema vodi nas prema uspostavi umjetničkog djela s obzirom na njegovog stvaraoca. Slijedeći takvo izlaganje, problematiziranje shvaćanja umjetnika nužno se oslanja na izvor samog djela. Time se uspostavlja pojmovna veza izvora umjetničkoga i samoga stvaraoca umjetničkog djela - od antičkog mimesisa i s njime povezanih umjetnika kao nositelja onoga techne i umjetničke produkcije shvaćene gotovo kao obrtništva, do romantičarskog genija kojemu je pretpostavka stvaranje u slobodi i autonomiji. $\mathrm{Na}$ isti način koncipiraju se i ostala poglavlja, a umjetničko djelo tumači se i s obzirom na osjećajnost i namjeru, pri čemu se intencionalnost shvaća kao konstitutivna osobina umjetničkoga djela, nužan, ali ne i dovoljan uvjet umjetničkoga stvaralaštva. Tumačenja umjetnosti lišene intencije naznačuje se kao nemogućnost predviđanja svih značenja koja umjetničko djelo može proizvesti, ali izostaje snažnija analiza u tom pravcu. Štoviše, nemogućnost umjetnikovih predviđanja mogućih značenja tumači se kao intencija recipijenta $\mathrm{u}$ pristupanju interpretaciji djela. Utoliko je umjetnost ponovo moguće potvrditi kao stvaralaštvo. Provedena analiza otvara prostor tumačenja i umjetničkoga djela po sebi, dakako, u formalnom i gotovo esencijalističkom pravcu kao postojanje skupa nepromjenjivih i očekivanih karakteristika koje djelo mora imati. Sklop takvih karakteristika ipak je moguće dopuniti i relacijskim svojstvima djela pa je formalistički princip ipak nužno nadići i tumačiti djelo u svijetu koji ga okružuje i kojega je dio. U relaciji spram svijeta, umjetničko djelo nužno je izraz, ekspresija. Ipak, svaki izraz nije moguće tumačiti kao umjetnički pa se pretpostavlja poznati pojam reprezentiranja kao nužno svojstvo umjetničkoga djela, a koje, suvremeno shvaćeno, može sadržavati i semantička svojstva poput ljepote ili uzvišenosti. Time se pokazuje pomak od tradicionalno shvaćene umjetnosti, kao lijepe ili uzvišene, prema reprezentacijskom sustavu s mogućim i često ostvarenim semantičkim svojstvima koja su u korelaciji s temom ili sadržajem samoga djela. Ipak, djelo se može ostvariti i lišeno je semantičkih svojstava. Intencionalnost i sva navedena svojstva ipak za umjetničko djelo ne znače puno bez najvažnije relacije, one spram recipijenta ili subjekta umjetničkoga doživljaja. Recipijent je onaj koji djelo doživljava, kojega ono afektira. Recipijent percipira, osjetilno doživljava djelo, u njega se uživljava, razumije ga i interpretira, kod njega se razvija ukus i puno razvijanje mogućih značenja. Pođemo li od puke recepcije, a u različitim teorijama umjetnosti čista, neutralna recepcija odavno je nadiđena, naše osjetilno doživljavanje ujedno je i inter- pretacija, tumačenje pa i potvrđivanje struktura koje ponavljamo iz društva, naših etičkih, političkih i religijskih stavova. Ukratko, pretpostavka postojanja nevinoga oka odavno je oborena, a naturalizacija društvenih obrazaca i socijalno-epistemoloških postupaka zamijenjena je sveprisutnim konstruktivizmom. Sud ukusa, pritom, ostaje prisutan kao (inter)subjektivni angažman, ali biva propitan i kao društvena i institucionalna norma bilo u odnosu umjetničkoga djela spram publike, tržišta ili kulturnih i političkih institucija. Sva ta pitanja i probleme Finci je, opravdano, doveo do razmatranja umjetničkog djela na način estetike kao filozofske discipline ili, moguće je reći, na način filozofije umjetnosti koja osjetilno propituje istinu samog bitka način postojanja bića.

Ukoliko je poglavlje »Misliti umjetnost « moguće shvatiti kao uvod u samu bit problema i pregleda koje iznosi autor, utoliko poglavlje »Misliti estetsko« odgovara svojevrsnoj konkluziji. Od polazišne točke i uopće mogućnosti i potrebe da se misli umjetnost, Finci razmatra i mišljenje estetskog. Pri tom izvodu kritički je sagledana pozicija umjetnosti u kontekstu estetskog ili estetike kao filozofske discipline. Takva se kritička pozicija može sagledati na dva načina - jednom kao odnos estetike spram same umjetnosti, a drugi put kao pozicija estetike unutar filozofije i njenog sustava disciplina. Ukoliko je riječ o odnosu estetike spram umjetnosti, utoliko se estetski nedostatak otkriva u prvenstvu umjetnosti, u njenom činjenju ili djelovanju. Iako različita od umjetničke kritike ili povijesti umjetnosti, estetika u tom smislu pokazuje sličan princip nepotrebnosti za samu umjetnost, naime, to da postoji zbog svoga predmeta. Kontigentnost estetskoga za umjetnost i njeno područje stvaranja i djelovanja ostaje skriveno u brojnim pokušajima pretvaranja umjetnosti u filozofske teze i obratu stvarnog prvenstva umjetnosti nad estetskim. U tom je smislu kritiku estetskog, kakvu provodi Finci, moguće tumačiti kao svojevrsnu obranu izvornosti, autonomije i slobode umjetnosti. Takva se kritika estetskog, kao zaštita umjetničkog, i prema samom autoru već odvijala u povijesti filozofije, a najjasnije je izražena u kritici estetike onih od kojih bi se očekivalo da joj budu skloni. Raspravljajući o za estetiku najutjecajnim radovima, Finci navodi nekoliko autora i njihovih djela. Neka od imena su Platon, Aristotel, Kant, Hegel i Benjamin. Iako se smatraju općim mjestima, ovdje istaknuti radovi navode se kao ključni doprinosi estetici, ali ujedno i kao mjesto njenog osporavanja (»U svakom od navedenih tekstova estetika je uspostavljana, a zbog svakog ili u svakom bila nanovo propitivana i nerijetko osporavana«, str. 397). Time se pokazuje da je estetika, 
ukoliko se umjetnost shvaća kao nositeljicu idejnosti, utoliko ipak nedovoljna i da umjetnosti preostaje više od statusa medija ideje. U drugom smislu, estetika se kao disciplina propituje unutar same filozofije. Shvaćena kao pomoćna disciplina ovisna o svom predmetu, estetika je upravo ovisna o spomenutoj ideji. Izgradivši se na autoritetu i moći klasičnih djela filozofije, estetika se gotovo sama osudila na status pomoćne discipline vezane uz osjetilni objekt. Kao mišljenje bitka, estetika tako pokazuje epistemološki karakter, ona je pojmovno utemeljenje umjetnosti koje se, kao i u prvom smislu, za umjetnost pokazuje nedovoljnim. Umjetnosti preostaje više od prijenosa ideje te osjetilne transfiguracije filozofije i mišljenja, koliko god to povratno potvrđivalo da je spekulacija o svijetu uvijek o onakvome svijetu kojega je dio i estetsko i bez kojega svijet o kojem filozofija govori ne može biti bez estetskog iskustva. Umjetnost tako nije moguće izjednačiti s osjetilnim prijenosom ideje neke (bilo koje) filozofije ili filozofskog sustava ni s oblikom diskurzivnog i pojmovnog mišljenja.

Shvaćena kao filozofska disciplina sa svojim ograničenjima i orijentiranošću na osjetilni objekt, estetika ipak treba biti zadržana; njen kraj nije uvjet očuvanja izvornosti i autonomije umjetnosti. Tako se izvodi i zadatak koji bi estetika sebi trebala postaviti - vraćanje vlastitom predmetu i njegovo istinsko razumijevanje. Ako se ona sama uistinu pita o fenomenu i vrijednosti umjetnosti, u estetici se ostvaruje dvostrukost i uzajamnost umjetnosti i estetike. Umjetničko djelovanje prethodi estetici kao rasuđivanju, ali tek u estetici umjetnost može biti shvaćena kao pitanje o osjetilnosti samog bitka.

\section{Marko Kardum}

doi: $10.21464 /$ fi36115

\section{$\underline{\text { Hotimir Burger }}$}

\section{Ljudsko odnošenje}

\section{Studije o relacijskoj antropologiji}

Nakladni zavod Globus, Zagreb 2014.

Imajući na umu tezu o čovjeku kao mikrokozmosu - koja razumijeva čovjeka kao kozmos u malom - i držeći ga na taj način reprezentativnim za kozmos u cijelosti, autor knjige Ljudsko odnošenje. Studije o relacijskoj an- tropologiji Hotimir Burger vodi čitatelja prema osvještenju iskustva odnosa kao odnosa. Iskustvo je to koje autor drži krucijalnom točkom u čovjekovu probijanju u vlastiti, ljudski svijet i u njegovu uljuđivanju svijeta. Ovo iskustvo odnosa kao odnosa sastavni je i utemeljujući dio svakoga znanja i mišljenja i na taj način sačinjava osnovu filozofske antropologije kojoj se - kako to autor pokazuje detaljno razloživši i istraživši povijesno-kritički taj problem u posljednjoj studiji u knjizi pod naslovom »Filozofska antropologija kao prva filozofija - u kontekstu suvremene filozofije pridaje status prve filozofije.

Ovakvu antropologiju Burger razumijeva kao relacijsku antropologiju čija je temeljna dimenzija upravo naznačeno iskustvo odnosa kao odnosa koje autor tematizira u svojoj prvoj studiji - već objavljenoj u njegovoj knjizi Ljudska moralnost (Zagreb 2008.) - pod naslovom »Čovjek kao tvorac odnosa«. Na temelju iščitavanja određenih tekstova četiriju filozofa - S. Kierkegaarda, K. Marxa, H. Plessnera i E. Cassirera - autor, promišljajući o iskustvu odnosa kao odnosa, osvještava tu posebnu ljudsku mogućnost i tu osobitu dimenziju ljudskoga bitka. Bitna odlika čovje$\mathrm{ka}$ - naglašava Burger - sastoji se u tome da stvara odnose. Mislioci kojima se autor bavi ukazuju u svojim spisima - svatko na svoj način, iz čega onda razvijaju vlastito razumijevanje ljudskoga bitka - na činjenicu da se naša zbiljnost odvija u odnosima i da oni određuju kako se ponašamo u vremenu i prostoru te u životnim situacijama i vremenskim razdobljima. Odnos kao odnos je - pokazuje Burger - veza između pojava i entiteta, pri čemu entiteti otkrivaju svoju bit. Čovjeka se, $\mathrm{u}$ tom smislu, kod svih mislioca razotkriva kao sebstvo koje se nalazi u poziciji unutarnje distance u odnosu spram sebe, spram okoline i spram drugih bića i koje je upravo takvoga odnosa kao odnosa svjesno i koji je kao takav za njega prezentan. Čovjek se, dakle, može odnositi ponajprije zbog iskustva unutarnje distance koja je mogućnost odmaka spram samoga sebe i mogućnost odmaka od drugoga. Tek na taj način, naime, čovjek može biti subjekt koji može odnose stvarati, tj. može svoje odnose spram drugih i spram stvari mijenjati i može djelovati svrhovito jer mu mogućnost vlastitoga izvornoga iskustva odnosa kao odnosa omogućuje bivanje u odnosima i izvan njih. To iskustvo - zaključuje Burger - tvori osnovu čovjekova otvaranja novih dimenzija zbiljnosti u teorijskom i praktičnom pogledu, kao i osnovu promjene same zbiljnosti, osnovu tvorbe novih odnosa u koje čovjek ulazi ili se od njih odmiče.

Konkretizaciju ove tvorbe novih odnosa, u koje čovjek ulazi ili se od njih odmiče, au- 